Mazzotti, s., and, Townend, ena-stress-suppl-A.txt seismic zones

Supplementary Material A: Focal mechanisms for central and eastern Canada and U.S.A

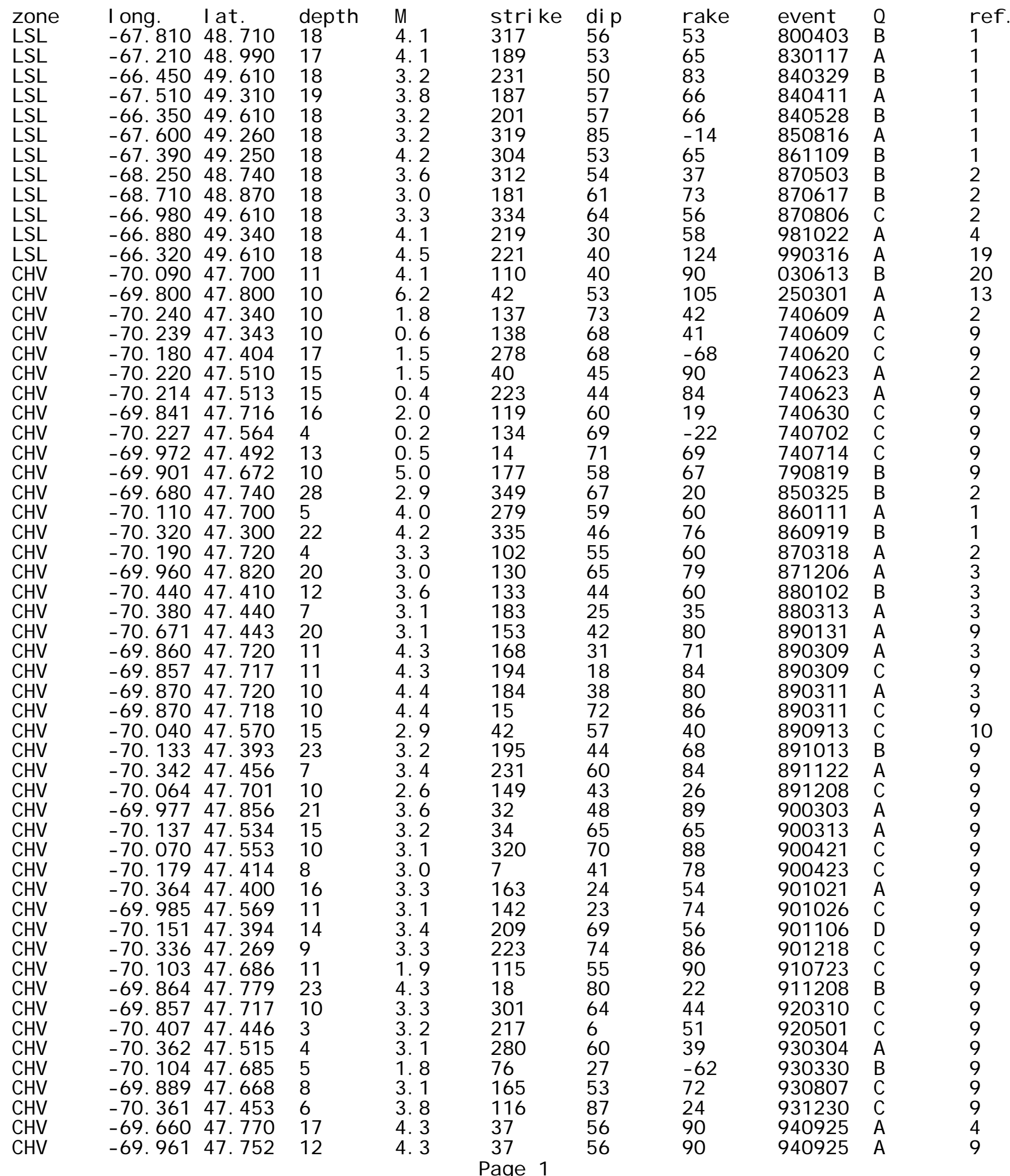




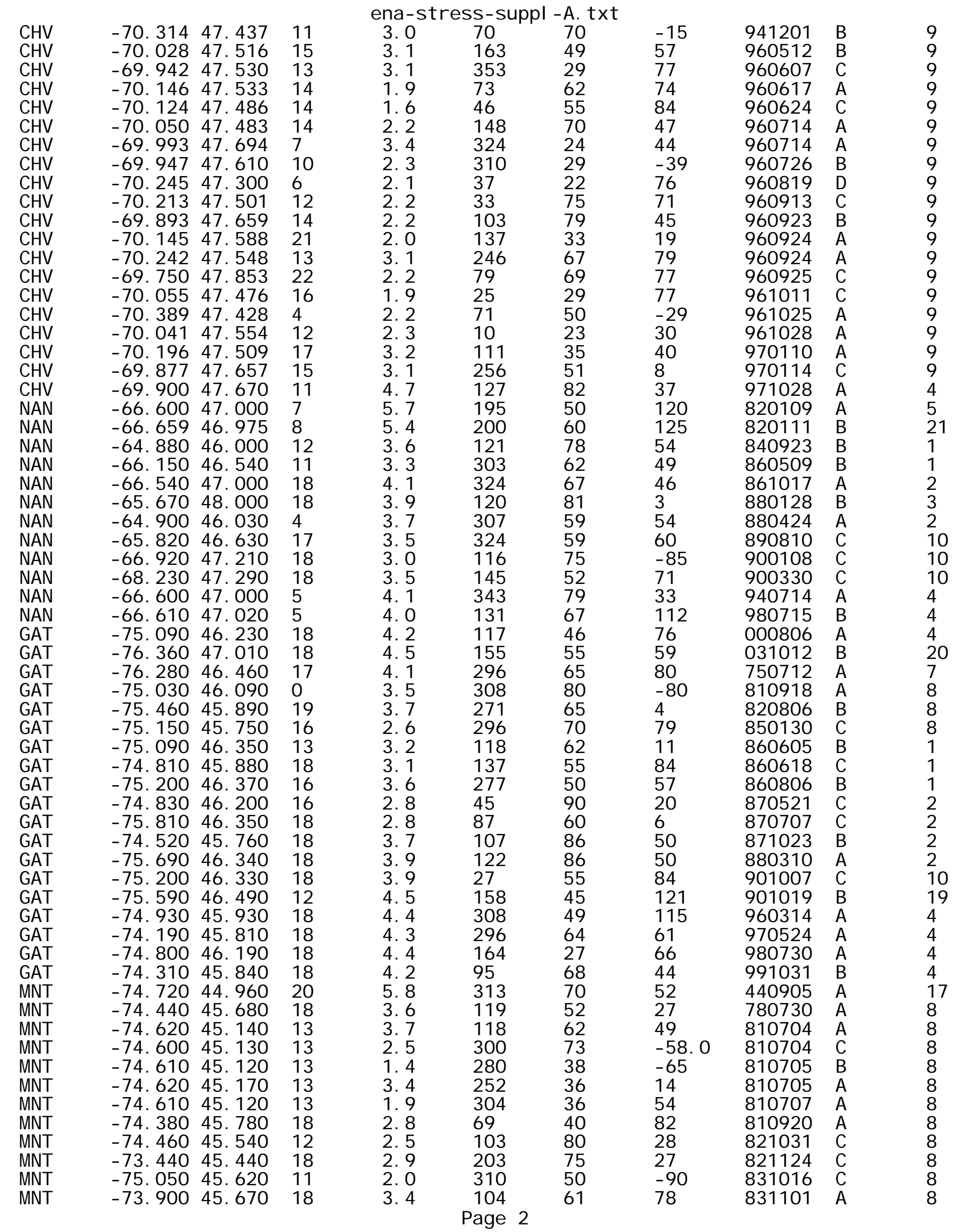




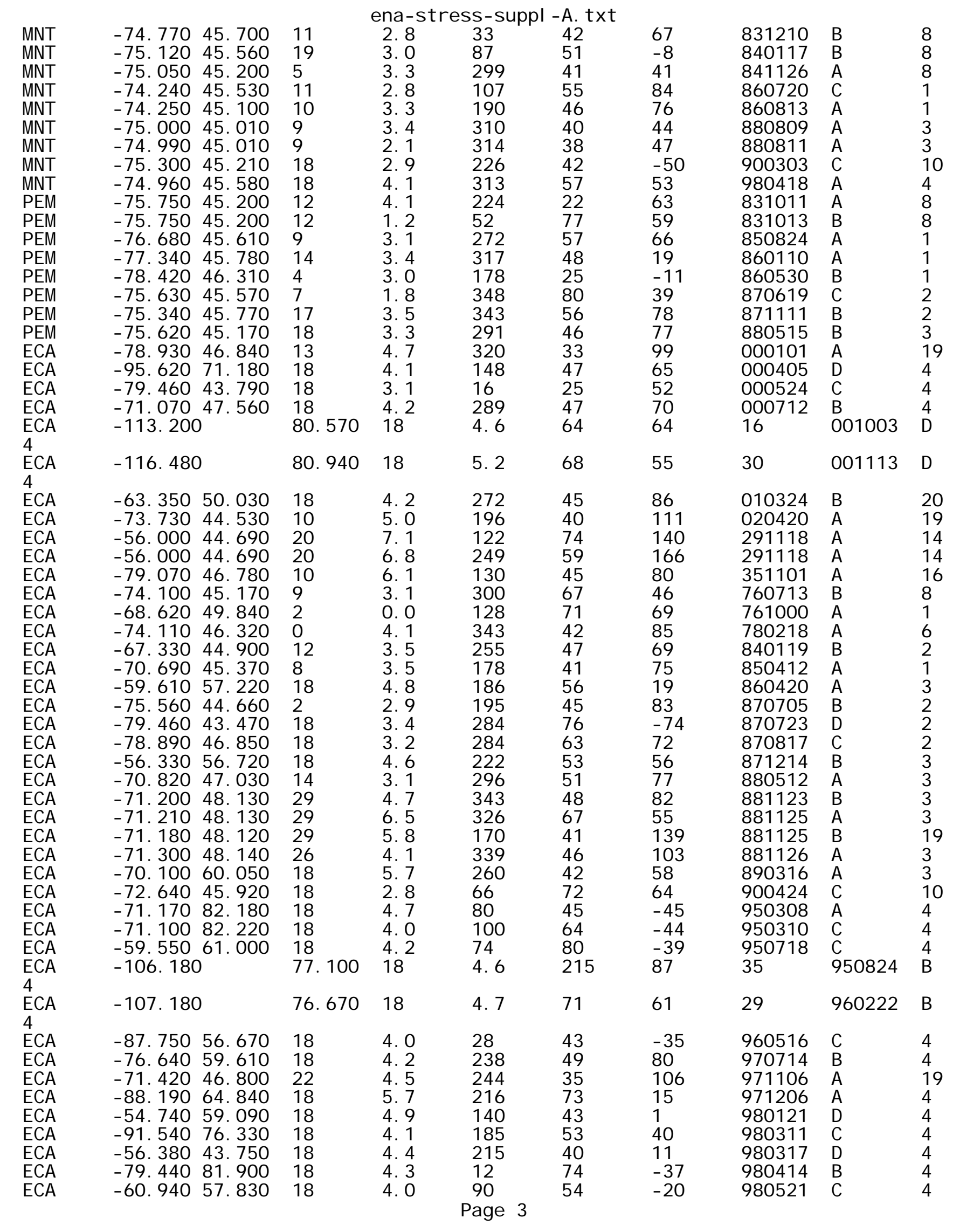




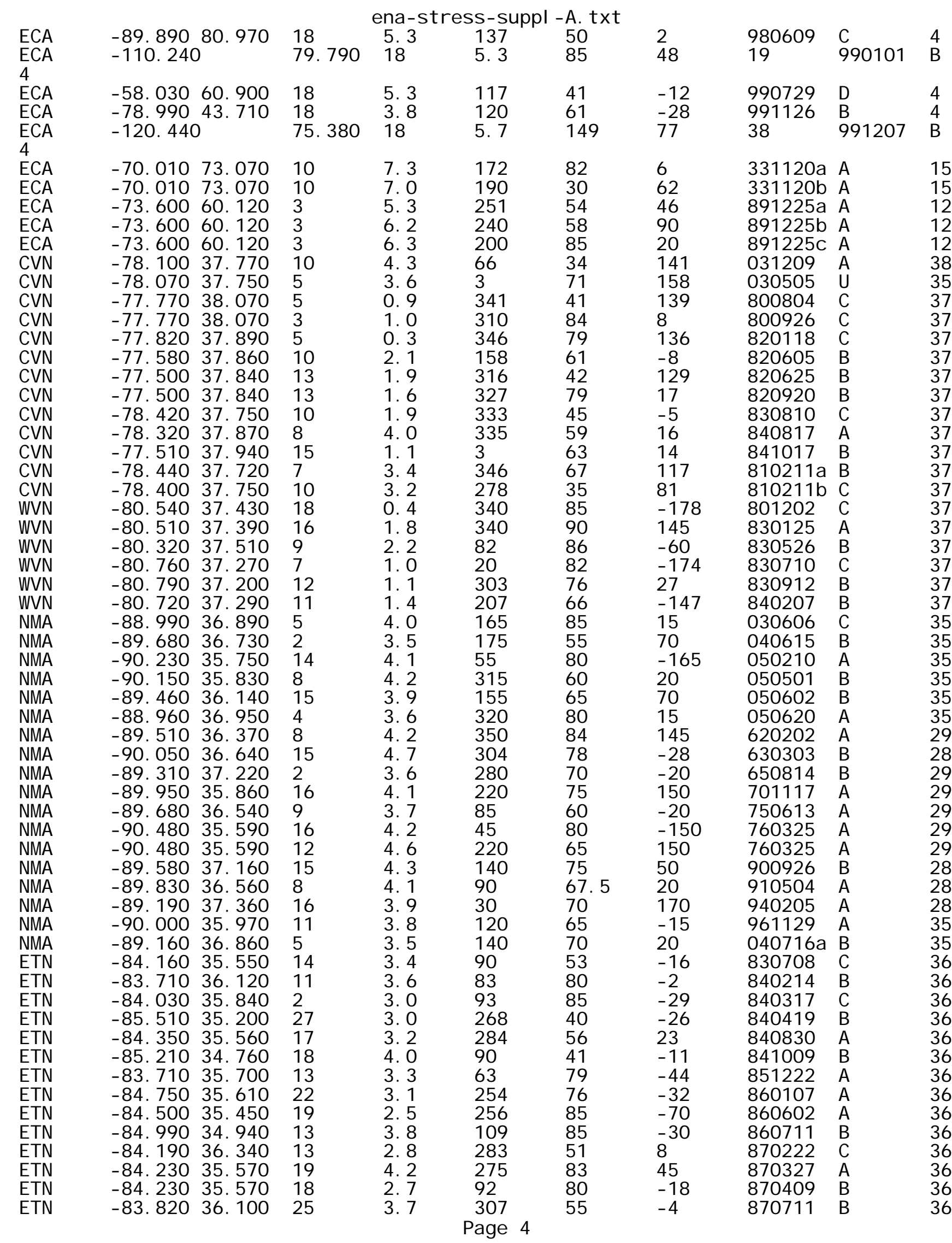




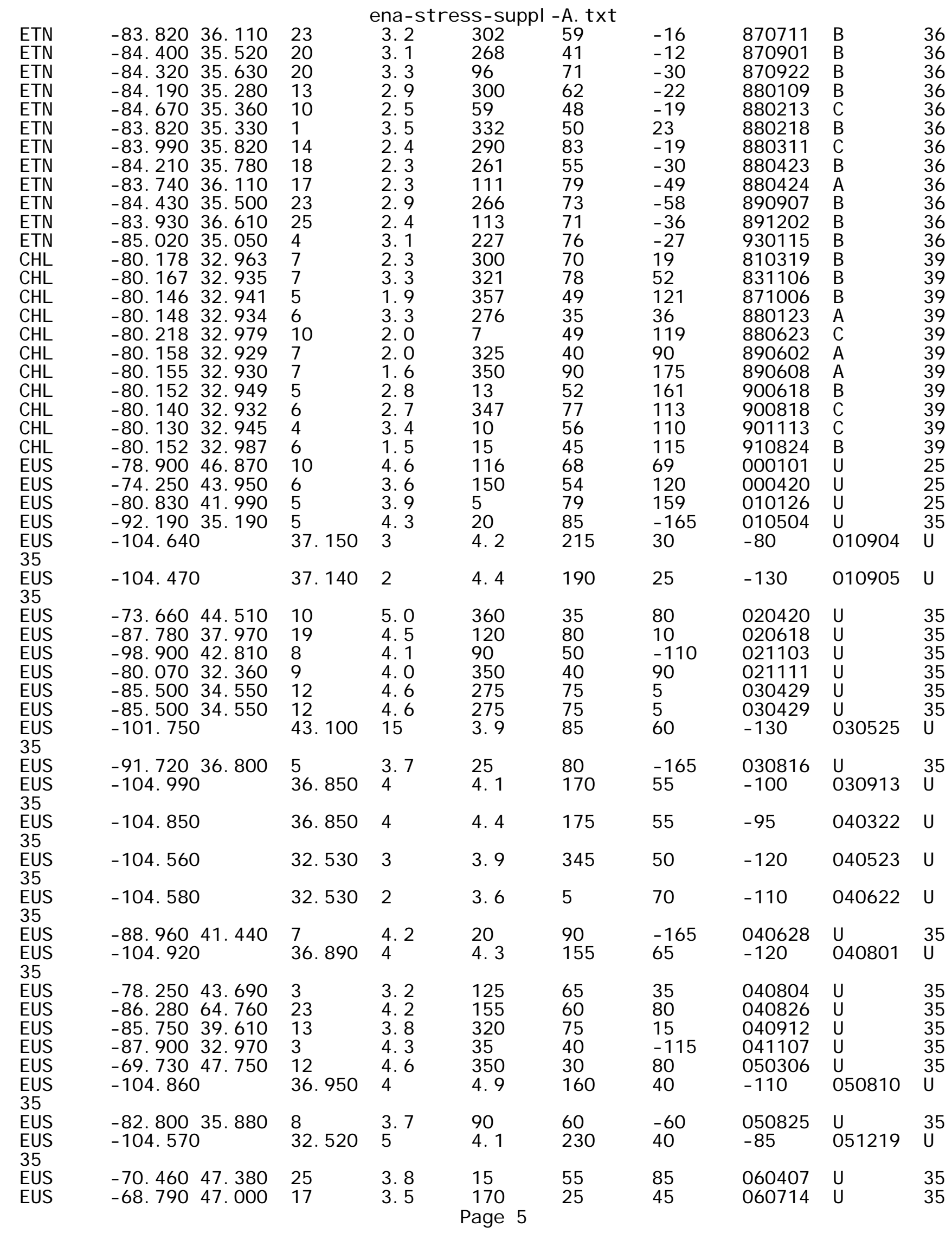




\begin{tabular}{|c|c|c|c|c|c|c|c|c|c|}
\hline $\begin{array}{l}\text { EUS } \\
\text { EUS }\end{array}$ & $\begin{array}{l}-68.17044 .330 \\
-104.900\end{array}$ & $\begin{array}{l}2 \\
37.060\end{array}$ & $\begin{array}{l}\text { ena. } \\
3.9 \\
2\end{array}$ & $\begin{array}{r}\text { S S. S } \\
340 \\
4.4\end{array}$ & $\begin{array}{l}\text { A. tx } \\
35 \\
205\end{array}$ & $\begin{array}{l}85 \\
50\end{array}$ & $\begin{array}{l}061003 \\
-60\end{array}$ & $\begin{array}{l}U \\
070103\end{array}$ & 35 \\
\hline $\begin{array}{l}\text { EUS } \\
\text { EUS }\end{array}$ & $\begin{array}{l}-96.27022 .020 \\
-104.790\end{array}$ & $\begin{array}{l}11 \\
36.930\end{array}$ & $\begin{array}{l}5 \cdot 6 \\
4\end{array}$ & $\begin{array}{l}190 \\
3.4\end{array}$ & $\begin{array}{l}75 \\
195\end{array}$ & $\begin{array}{l}-160 \\
50\end{array}$ & $\begin{array}{l}070523 \\
-60\end{array}$ & $\begin{array}{l}U \\
070609\end{array}$ & 35 \\
\hline $\begin{array}{l}\text { EUS } \\
E \cup S \\
E \cup S\end{array}$ & $\begin{array}{l}-90.940 \quad 37.480 \\
-78.20042 .800 \\
-104.800\end{array}$ & $\begin{array}{l}5 \\
2 \\
39.900\end{array}$ & $\begin{array}{l}4.6 \\
4.3 \\
4\end{array}$ & $\begin{array}{l}260 \\
110 \\
4.5\end{array}$ & $\begin{array}{l}40 \\
70 \\
165\end{array}$ & $\begin{array}{l}-70 \\
20 \\
52\end{array}$ & $\begin{array}{l}651021 \\
660101 \\
-174\end{array}$ & $\begin{array}{l}A \\
A \\
670410\end{array}$ & $\begin{array}{l}29 \\
29 \\
U\end{array}$ \\
\hline $\begin{array}{l}\text { EUS } \\
\text { EUS } \\
\text { EUS }\end{array}$ & $\begin{array}{l}-78.20042 .900 \\
-90.44037 .440 \\
-104.700\end{array}$ & $\begin{array}{l}3 \\
15 \\
39.900\end{array}$ & $\begin{array}{l}4.1 \\
4.0 \\
3\end{array}$ & $\begin{array}{l}130 \\
350 \\
4.8\end{array}$ & $\begin{array}{l}50 \\
60 \\
130\end{array}$ & $\begin{array}{l}40 \\
135 \\
35\end{array}$ & $\begin{array}{l}670613 \\
670721 \\
-90\end{array}$ & $\begin{array}{l}A \\
B \\
670809\end{array}$ & $\begin{array}{l}29 \\
28 \\
U\end{array}$ \\
\hline EUS & .104 .700 & 40.000 & 5 & 4.5 & 158 & 52 & .63 & 671127 & U \\
\hline $\begin{array}{l}\text { EUS } \\
\text { EUS } \\
\text { EUS } \\
\text { EUS } \\
\text { EUS } \\
\text { EUS } \\
\text { EUS } \\
\text { EUS } \\
\text { EUS } \\
\text { EUS }\end{array}$ & 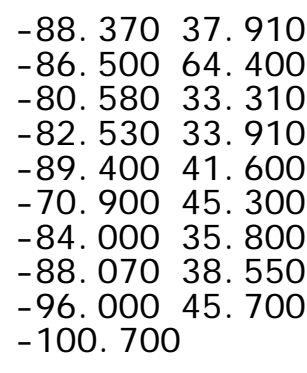 & $\begin{array}{l}22 \\
12 \\
2 \\
2 \\
13 \\
6 \\
13 \\
15 \\
8 \\
33.000\end{array}$ & $\begin{array}{l}5 \cdot 3 \\
4 \cdot 6 \\
4 \cdot 4 \\
4 \cdot 0 \\
4 \cdot 1 \\
4 \cdot 5 \\
4 \cdot 1 \\
4.3 \\
4.3 \\
3\end{array}$ & $\begin{array}{l}0 \\
162 \\
260 \\
350 \\
170 \\
300 \\
190 \\
310 \\
330 \\
4.5\end{array}$ & $\begin{array}{l}46 \\
72 \\
40 \\
65 \\
70 \\
80 \\
70 \\
70 \\
90 \\
260\end{array}$ & $\begin{array}{l}79 \\
90 \\
10 \\
100 \\
160 \\
70 \\
150 \\
0 \\
160 \\
60\end{array}$ & $\begin{array}{l}681109 \\
711002 \\
720203 \\
720802 \\
720915 \\
730615 \\
731130 \\
740403 \\
750709 \\
-60\end{array}$ & $\begin{array}{l}A \\
A \\
U \\
U \\
B \\
A \\
C \\
B \\
B \\
780616\end{array}$ & $\begin{array}{l}29 \\
29 \\
24 \\
24 \\
29 \\
29 \\
29 \\
29 \\
29 \\
U\end{array}$ \\
\hline $\begin{array}{l}\text { EUS } \\
\text { EUS } \\
\text { EUS } \\
\text { EUS } \\
\text { EUS } \\
\text { EUS }\end{array}$ & 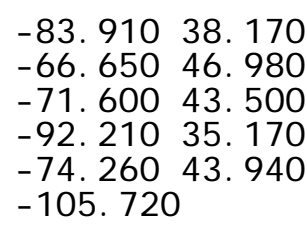 & $\begin{array}{l}12 \\
7 \\
8 \\
6 \\
9 \\
42.370\end{array}$ & $\begin{array}{l}5.0 \\
5.1 \\
4.2 \\
5.0 \\
4.9 \\
25\end{array}$ & $\begin{array}{l}30 \\
200 \\
200 \\
330 \\
170 \\
5.3\end{array}$ & $\begin{array}{l}60 \\
60 \\
35 \\
60 \\
70 \\
350\end{array}$ & $\begin{array}{l}180 \\
125 \\
120 \\
55 \\
115 \\
60\end{array}$ & $\begin{array}{l}80007127 \\
82201111 \\
8250119 \\
82201121 \\
83110007 \\
335\end{array}$ & $\begin{array}{l}U \\
U \\
U \\
U \\
841018\end{array}$ & $\begin{array}{ll}2 & 3 \\
2 & 1 \\
2 & 1 \\
2 & 1 \\
2 & 1 \\
U\end{array}$ \\
\hline $\begin{array}{l}\text { EUS } \\
\text { EUS } \\
\text { EUS } \\
\text { EUS } \\
\text { EUS } \\
\text { EUS }\end{array}$ & 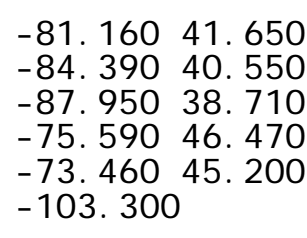 & $\begin{array}{l}6 \\
4 \\
10 \\
11 \\
12 \\
30.260\end{array}$ & $\begin{array}{l}4.7 \\
4.4 \\
5.0 \\
4.6 \\
3.9 \\
20\end{array}$ & $\begin{array}{l}25 \\
20 \\
135 \\
141 \\
144 \\
5.6\end{array}$ & $\begin{array}{l}80 \\
80 \\
70 \\
42 \\
45 \\
114\end{array}$ & $\begin{array}{l}165 \\
-170 \\
15 \\
90 \\
96 \\
64\end{array}$ & $\begin{array}{l}8600131 \\
860712 \\
870610 \\
901019 \\
931116 \\
-101\end{array}$ & $\begin{array}{l}U \\
U \\
U \\
U \\
950414\end{array}$ & $\begin{array}{l}21 \\
30 \\
31 \\
25 \\
25 \\
U\end{array}$ \\
\hline $\begin{array}{l}\text { EUS } \\
\text { EUS } \\
\text { EUS } \\
\text { EUS } \\
\text { EUS } \\
\text { EUS } \\
\text { EUS } \\
\text { EUS } \\
\text { EUS } \\
\text { EUS } \\
\text { EUS } \\
\text { EUS } \\
\text { EUS } \\
\text { EUS } \\
\text { EUS } \\
\text { EUS } \\
\text { EUS } \\
\text { EUS } \\
\text { EUS }\end{array}$ & 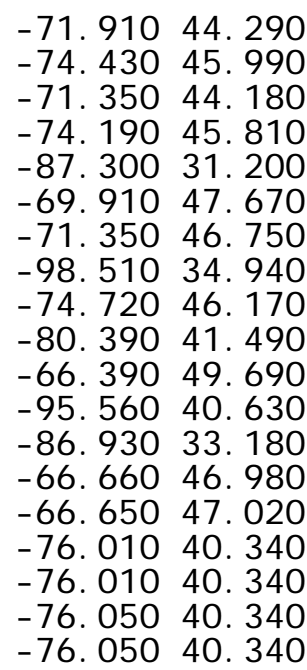 & $\begin{array}{l}6 \\
6 \\
7 \\
22 \\
5 \\
5 \\
12 \\
19 \\
9 \\
3 \\
5 \\
12 \\
4 \\
9 \\
6 \\
2 \\
3 \\
2 \\
3\end{array}$ & $\begin{array}{l}3.7 \\
3.7 \\
3.4 \\
3.6 \\
4.9 \\
4.3 \\
4.5 \\
3.9 \\
3.7 \\
4.5 \\
4.4 \\
3.5 \\
3.6 \\
5.5 \\
4.8 \\
4.0 \\
4.0 \\
4.6 \\
4.6\end{array}$ & $\begin{array}{l}95 \\
136 \\
144 \\
96 \\
94 \\
27 \\
39 \\
120 \\
150 \\
110 \\
30 \\
290 \\
30 \\
200 \\
215 \\
156 \\
121 \\
159 \\
135\end{array}$ & $\begin{array}{l}50 \\
36 \\
60 \\
33 \\
62 \\
60 \\
63 \\
70 \\
27 \\
70 \\
63 \\
5 \\
30 \\
45 \\
60 \\
45 \\
60 \\
48 \\
40\end{array}$ & $\begin{array}{l}40 \\
98 \\
93 \\
60 \\
-90 \\
111 \\
87 \\
-60 \\
75 \\
20 \\
93 \\
-135 \\
-100 \\
120 \\
130 \\
108 \\
66 \\
102 \\
68\end{array}$ & $\begin{array}{l}950616 \\
960314 \\
960821 \\
970524 \\
971024 \\
971028 \\
971106 \\
980428 \\
980730 \\
980925 \\
990316 \\
040716 b \\
040819 b \\
820109 a \\
820109 b \\
940116 a \\
940116 a \\
940116 b \\
940116 b\end{array}$ & $\begin{array}{l}U \\
U \\
U \\
U \\
U \\
U \\
U \\
U \\
U \\
U \\
U \\
U \\
U \\
U \\
U \\
U \\
U \\
U \\
U\end{array}$ & $\begin{array}{l}25 \\
25 \\
25 \\
25 \\
35 \\
25 \\
25 \\
35 \\
25 \\
34 \\
25 \\
35 \\
35 \\
21 \\
21 \\
25 \\
33 \\
25 \\
33\end{array}$ \\
\hline
\end{tabular}

zone: seismic zone - ECA: Eastern Canada; EUS: Eastern U.S.A. ; LSL: Lower St. 


\begin{abstract}
ena-stress-suppl-A.txt
Lawrence; CHV: Charlevoix; GAT: Gati neau; MNT: Montreal; NAN: North Appal achian; OTT: Ottawa Valley; CVN: Central Virginia; ETN: Eastern Tennessee; NMA: New Madrid; CHL: Charleston.
\end{abstract}

long., Iat., depth: I ongitude $\left({ }^{\circ} E\right)$, I atitude $\left({ }^{\circ} N\right)$ and depth $(\mathrm{km})$ of epicenter.

M: earthquake magnitude ( magnitude scale vary between events, cf. individual references).

strike, dip, rake: angle $\left({ }^{\circ}\right)$ of strike, dip, and rake of one of the two fault planes.

event: earthquake number defined as year, month, day (YYMMDD).

Q: quality factor of focal mechanism: A (highest) to C (lowest); U: undefined.

ref.: reference:

1. Adams, J., J. Sharp, and M. C. Stagg, 1988, New focal mechanisms for southeastern Canadian earthquakes, Geol. Surv. Canada Open File, OF1892, p. 112.

2. Adams, J., A. Vonk, D. Pittman, and H. Vatcher, 1989, New focal mechanisms for southeastern Canadian earthquakes II, Geol. Surv. Canada Open File, OF1995, p. 97. 3. Adams, J., 1991, New focal mechanisms for eastern Canada, Geol. Surv. Canada Open File, OF 2430, p. 118.

4 - Bent, A. L., J. Drysdale, and H. K. C. Perry, 2003, Focal mechanisms for eastern Canadian earthquakes: 1994-2000, Seism. Res. Lett., 74, 452-468.

5 - Wetmiller, R. J., J. Adams, F. M. anglin, H. S. Hasegawa, and A. E. Stevens, 1 984, Aftershock sequences of the 1982 Miramichi, New Brunswick, earthquakes, Bull. Seism. Soc. Amer., 74, 621-653.

6 - Horner, R. B., Wetmiller, R. J., and H. S. Hasegawa, 1979, The St-Donat, Quebec, earthquake sequence of February 18-23, 1978, Can. J. Earth. Sci., 16, 1892-1898.

7 - Horner, R. B., Stevens, A. E., Hasegawa, H. S., and G. LeBl anc, 1978, Focal parameters of the July 12, 1975, Mani waki, Quebec, Earthquake An example of intraplate seismicity in eastern Canada, Bull. . Seism. Soc. Amēr., 68, 619-640. 8 - Wahlstrom, R., 1987, Focal mechanisms of earthquakes in southern Quebec, southeastern Ontario, and northeastern New York with implications for regional sei smotectonics and stress field characteristics, Bull. Seism. Soc. Amer., 77, $891-924$.

9. Lamontagne, M., 1998, New and revised earthquake focal mechanisms for the Charlevoix seismic zone, Canada, Geol. Surv. Canada Open File, OF3556, p. 302.

10 - Seismological Service, Canadian Earthquakes National Summary, Natural Resources Canada, $1989-1990$.

11. Lamontagne, M., H. S. Hasegawa, D. A. Forsyth, G. G. R. Buchbinder, and M.

Cajka, 1994, The Mont-Laurier, Quebec, earthquake of 19october 1990 and its

seismotectonic environment, Bull. Seism. Soc. Amer., 84, 1506-1522.

12 - Bent, A. L., 1994, The 1989 (Ms 6.3) Ungava, Quebec, Earthquake: a complex intraplate event, Bull. Seism. Soc. Amer., 84, 1075-1088.

13 - Bent, A. L., 1992, A re-exami nation of the 1925 Charlevoix, Quebec, earthquake, Bull. Seism. Soc. Amer., 82, 2097-2113.

14 . Bent, A. L., 1995,' A complex double-couple source mechanismfor the Ms 7.21929 Grand Banks earthquake, Bull. Seism. Soc. Amer., 85, 1003-1020.

15 - Bent, A. L., 2002, The 1933 Ms =7.3 Baffin Bay earthquake: strike-slip faulting along the northeastern Canadian passive margin, Geophys. I Int., 150,724-736.

16 - Bent, A. L., 1996, An i mproved source mechanism for the 1935 Timiskaming,

Quebec, earthquake from regional waveforms, Pure Applied Geophys.,146, 1-20.

17 - Bent, A. L., 1996, Source parameters of the damaging Cornwall-Massena

earthquake of $1944 \mathrm{from} \mathrm{regional} \mathrm{waveforms,} \mathrm{Bull.} \mathrm{Seism.} \mathrm{Soc.} \mathrm{Amer.,} \mathrm{86,} \mathrm{489-497.}$

18 - Lamontagne, M., A. L. Bent, C. R. D. Woodgold, S. Ma, V. Peci, 2004, The 16

March 1999 mn 5.1 Cote-Nord earthquake: the largest earthquake ever recorded in the

lower St. Lawrence seismic zone, Canada, Seism. Res. Lett., 75, 299-313.

19 - Ma, S., 2004, Personal communication.

20 - Bent, A. L., 2004, Personal communication.

21 - Nguyen, B. V., and R. B. Herrmann, 1992, Determination of source parameters for central and eastern North America earthquakes (1982-1986), Seism. Res. Lett., 63, 
$567-577$.

ena-stress-suppl-A.txt

22 - Herrmann, R. B., C. Y. Wang, and S. - K. Park, 1981, The Denver earthquakes of 1967-1968, Bull. Seism. Soc. Am., 71, 731-746.

23 - Herrmann, R. B., C. A. Langston, and J. E. Zoll weg, 1982, The Sharpsburg,

Kentucky earthquake of July 27, 1980, Bull. Seism. Soc. Am., 72, 1219-1239.

24 - Herrmann, R. B., 1986, Surface-wave studies of some South Carolina earthquakes,

Bull. Seism. Soc. Am. 76, 111-121.

25 - Du, W. X., W. Y. Ki m, and L. R. Sykes, 2003, Earthquake Source Parameters and

State of Stress for the Northeastern United States and Southeastern Canada from

Analysis of Regional Seismograms, Bull. Seism. Soc. Am., 93, 1633-1648.

26 - Chang, T. M. , 1997, Evaluation of Surface-Wave Waveform Modeling for Lithosphere

Velocity Structure, Ph. D. Dissertation, Saint Louis University.

27 - Voss, J. A., and R. B. Herrmann, 1980, A surface wave study of the June 16,

1978 Texas earthquake, Earthquake Notes, 51, 3-14.

28. Herrmann, R. B., and C. J. Ammon, 1997, Faulting parameters of earthquakes in

the New Madrid, Missouri region, Enginer. Geol., 46, 299-311.

29. Herrmann. R. B. 1979, Surface wave focal mechanisms for eastern North American earthquakes with tectonic i mplications, J. Geophys. Res., 84, 3543-3552.

30 . Schwartz, S. Y., and D. H. Christensen, 1988, The 12 July St. Marys, Ohio earthquake and recent seismicity in the Anna, Ohio seismogenic zone, Seism. Res. Let t. , 59, $57-62$.

31. Taylor, K. B., R. B. Herrmann, M. W. Hamburger, G. L. Pavlis, A. Johnston, C. Langer and C. Lam, 1989, The southeastern IIli nois earthquake of $10 \mathrm{~J}$ une 1987 ,

Seism. Res. Lett., $60,101-110$.

32 - Nguyen, B. V., and R. B. Herrmann, 1992, Determi nation of source parameters for central and eastern North American earthquakes (1982-1986), Seism. Res. Lett., 63,

$567-586$.

33 - Ammon, C. J., R. B. Herrmann, C. A. Langston, and H. Benz, 1998, Source parameters of the January 16, 1994 Wyomi ssing Hills, Pennsylvani a earthquakes, Seism. Res. Lett., 69, 261-269.

34 - Maceira, M., C. J. Ammon and R. B. Herrmann, 2000 , Faulting parameters of the September 25, 1998 Pymatuning, Pennsylvania earthquake, Seism. Res. Lett., 71, $742-752$.

35 - Moment Tensor Solutions, Saint Louis Univ., Dep. Earth Atm. Sci., web site; htt p: / / www. eas. sl u. edu/Earthquake Center / MECH. NA/ index. ht ml.

36 - Chapman, M. C., C. A. Powel, G. VI ahovic, and M. S. Sibol, 1997, A statistical analysis of earthquake focal mechanisms and epicenter locations in the Eastern Tennessee seismic zone, Bull. Seism. Soc. Am., 87, 1522-1536.

37. Munsey, J. W., and G. A. Bollinger, 1985, Focal mechanism analyses for Virginia earthquakes, Bull', Seism. Soc. Amer., 75, 1613-1636.

38 - Kim, W. Y., and M. Chapman, The 9 December 2003 central Virginia earthquake sequence: A compound earthquake in the Central Virginia seismic zone, Bull. Seism. Soc. Amer., 95, 2428-2445.

39. Madabhushi, S., and P. Tal wani, 1993, Fault plane solutions and relocations of recent earthquakes in Middleton Place Summerville seismic zone near Charleston,

South Carolina, Bull. Seism. Soc. Amer., 83, 1442-1466. 
Mazzotti, S., and J. Townend, state of stress in central and eastern North America seismic zones

Supplementary Material B: Octant plots of focal mechanisms

This supplement presents octant plots of the focal mechanisms used for the stress inversion in each seismic zone (Fig. Bl). The octant plots (also called eigenvector representation) are based on the formulation developed in Kagan (2005). As shown in Figure B1, the diversity of mechanisms varies signicantly between seismic zones. Zones such as Lower St. Lawrence or ottawa are characterized by mechanisms that are mostly si milar (mainly reverse-fault mechanisms in those two cases). In contrast, zones such as Montreal or Charlevoix show higher diversity with mechanisms varying between reverse, strike-slip, and normal faulting.

Figure B1: Octant plots of focal mechanisms in central and eastern North America seismic zones. Grey triangles represent individual focal mechanisms. Plunge angles of $30^{\circ}$ and $60^{\circ}$ shown by thin solid li nes. Boundaries between strike-slip, normal and reverse faulting shown by dashed I i nes. RF: reverse fault; NF: normal fault; sS: strike-slip.

References

Kagan, Y. Y., 2005, Double-couple earthquake focal mechanisms: random rotation and display, Geophys. J. Int., 163, 1065-1072. 
Mazzotti, S., and J. Townend, state of stress in central and eastern North America seismic zones

Supplementary Material c: Stress inversions for groups of mechanisms in the Charlevoix seismic zone

This supplement presents the results of inversion tests for various groups of earthquake focal mechanisms in the Charlevoix seismic zone (Fig. C1): Inside and outside the inner perimeter of i mpact crater (1a, b), inside and outside the outer perimeter of impact crater (2a, b), northern cluster (3), southeast central cluster (4), northwest central cluster (5), southern cluster (6), northern half (7), southern half (8), entire dataset (9), southeast (10 and northwest (11) clusters (cf. Section 4.4 ).

Groups of mechanisms located entirely or mainly to the northwest of the charlevoix Fault (1a, 5 and 6, Table C1) are associated with a SH azimuth about N050-060\%, similar to the orientation obtained for the northwest group (11, Table C1). Groups of mechanisms located entirely or mainly to the southeast of the charlevoix fault (4, Table c1) or at the northern end of the seismic zone (2b and 3, Table c1) are associated with a SH azimuth about N100-1200, similar to the orientation obtained for the southeast group (10, Table c1). Other groups, which include mechanisms located roughly evenly across the charlevoix Fault (1b, $2 a, 7$ and 8 , Table C1), are associated with an intermediate SH azimuth of about N070-090..

There is no clear indication of significant variations in sH orientation inside versus outside the i mpact crater or as a function of depth. A previously postulated SH rotation with depth (Adams and Bell, 1991) is likely an artifact arising from the heterogeneous l ateral distribution of earthquakes within depth slices. Observed rotations for these groups are related to the location of mechanisms primarily to the southeast or northwest of the Charlevoix seismic zone (e.g., $2 b$, Table c1).

Table C1. Maximum horizontal stress median orientation (SH) and go\% confidence interval $(90 \mathrm{ClH})$ for various groups.

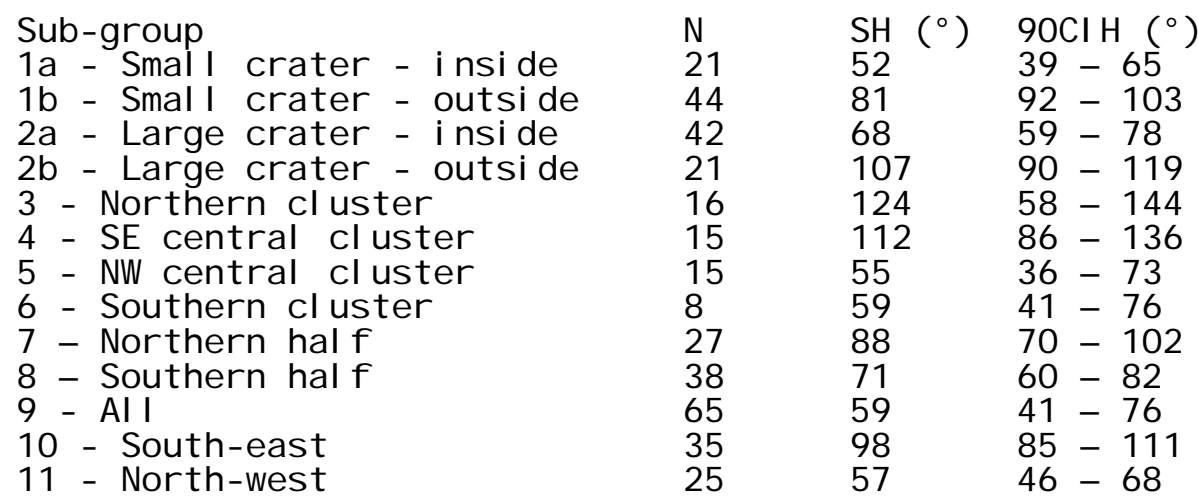

Figure C1: Locations of focal mechanism groups for the Charlevoix seismic zone. Large grey circles show epicenters of focal mechanism events. Numbers refer to groups (cf. text). Small and large dashed circles show extent of inner and outer perimeter of charlevoix i mpact crater. 


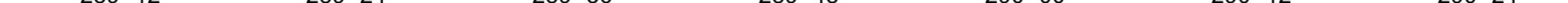









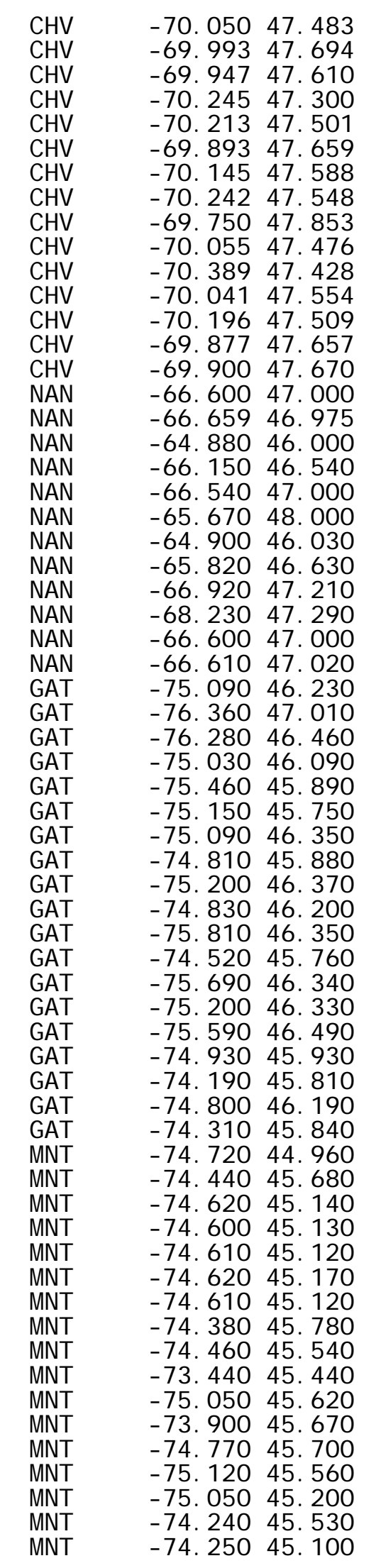

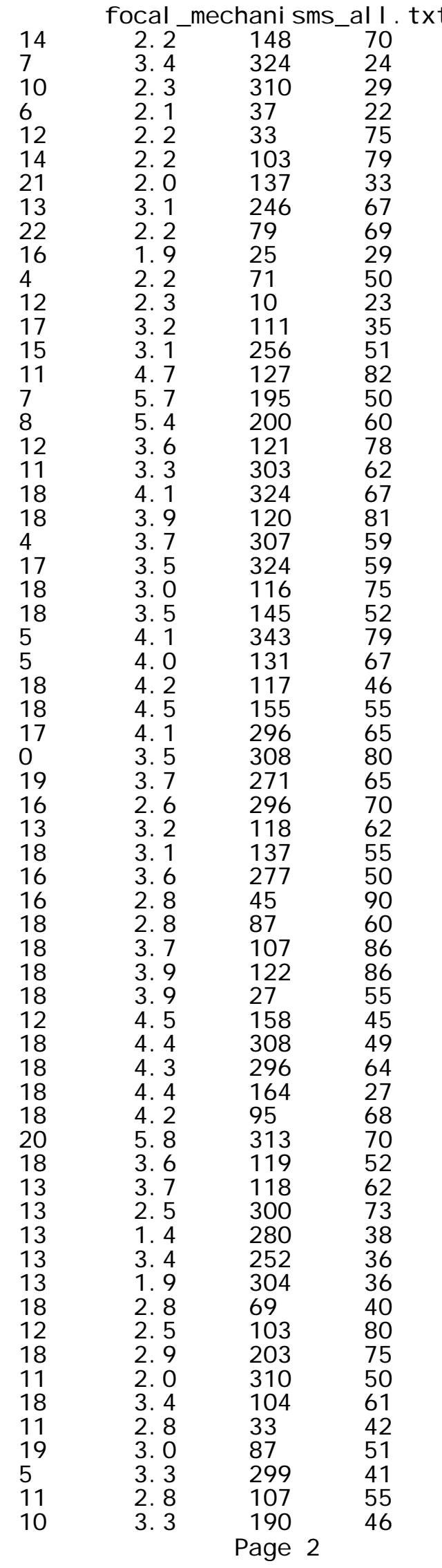

\begin{tabular}{|c|c|c|}
\hline 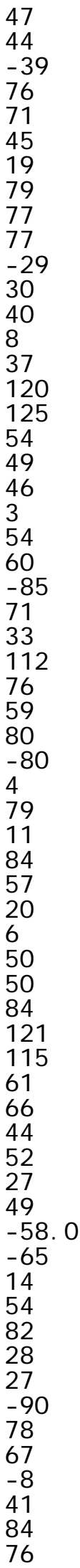 &  & $\begin{array}{l}A \\
A \\
B \\
D \\
D \\
C \\
B \\
A \\
A \\
C \\
C \\
C \\
A \\
A \\
A \\
C \\
A \\
A \\
A \\
B \\
B \\
B \\
A \\
B \\
A \\
C \\
C \\
C \\
A \\
B \\
A \\
B \\
A \\
A \\
B \\
C \\
B \\
C \\
B \\
C \\
C \\
B \\
A \\
C \\
B \\
A \\
A \\
A \\
B \\
A \\
A \\
A \\
C \\
B \\
A \\
A \\
A \\
C \\
C \\
C \\
C \\
A \\
B \\
B \\
A \\
A \\
C \\
A\end{array}$ \\
\hline
\end{tabular}




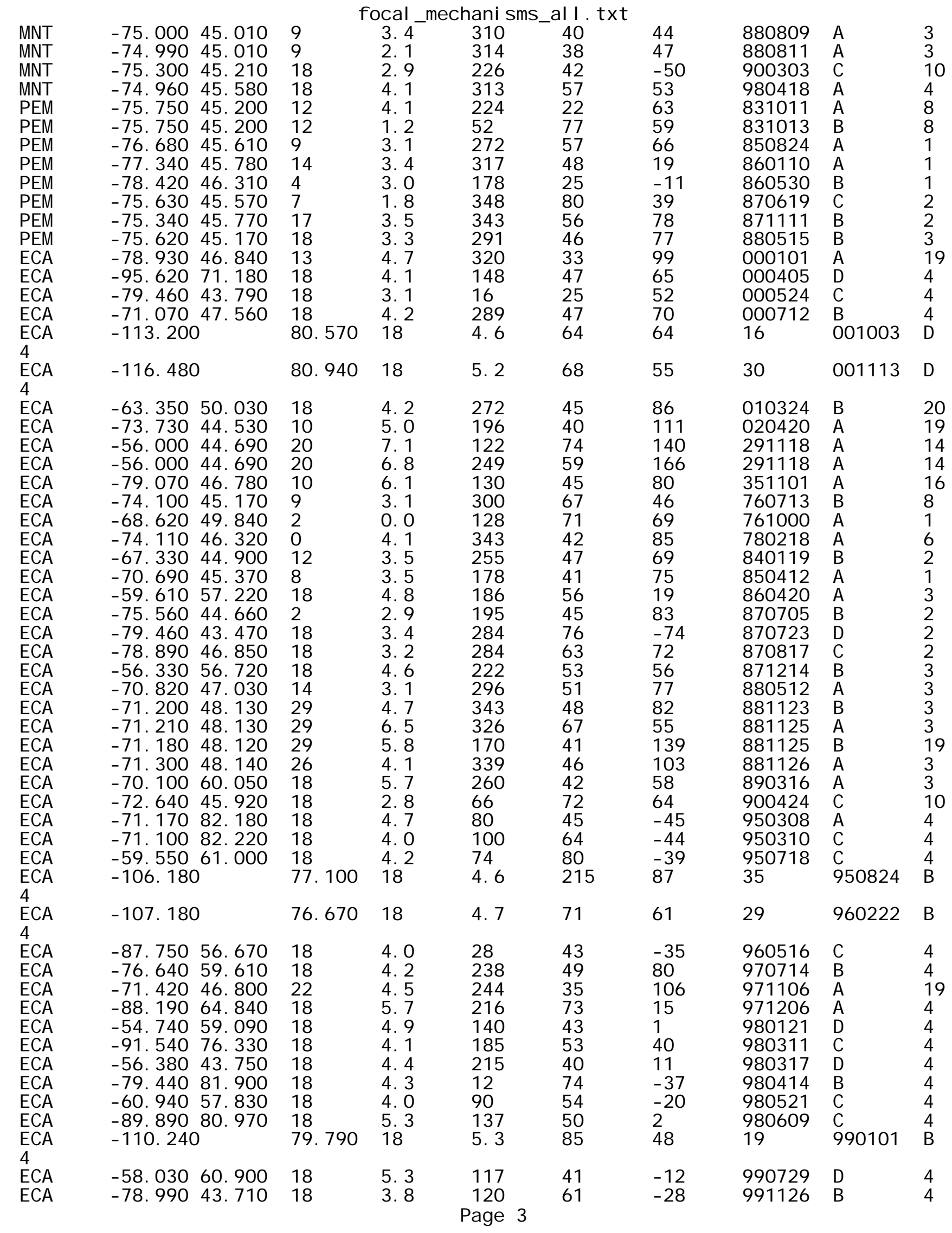




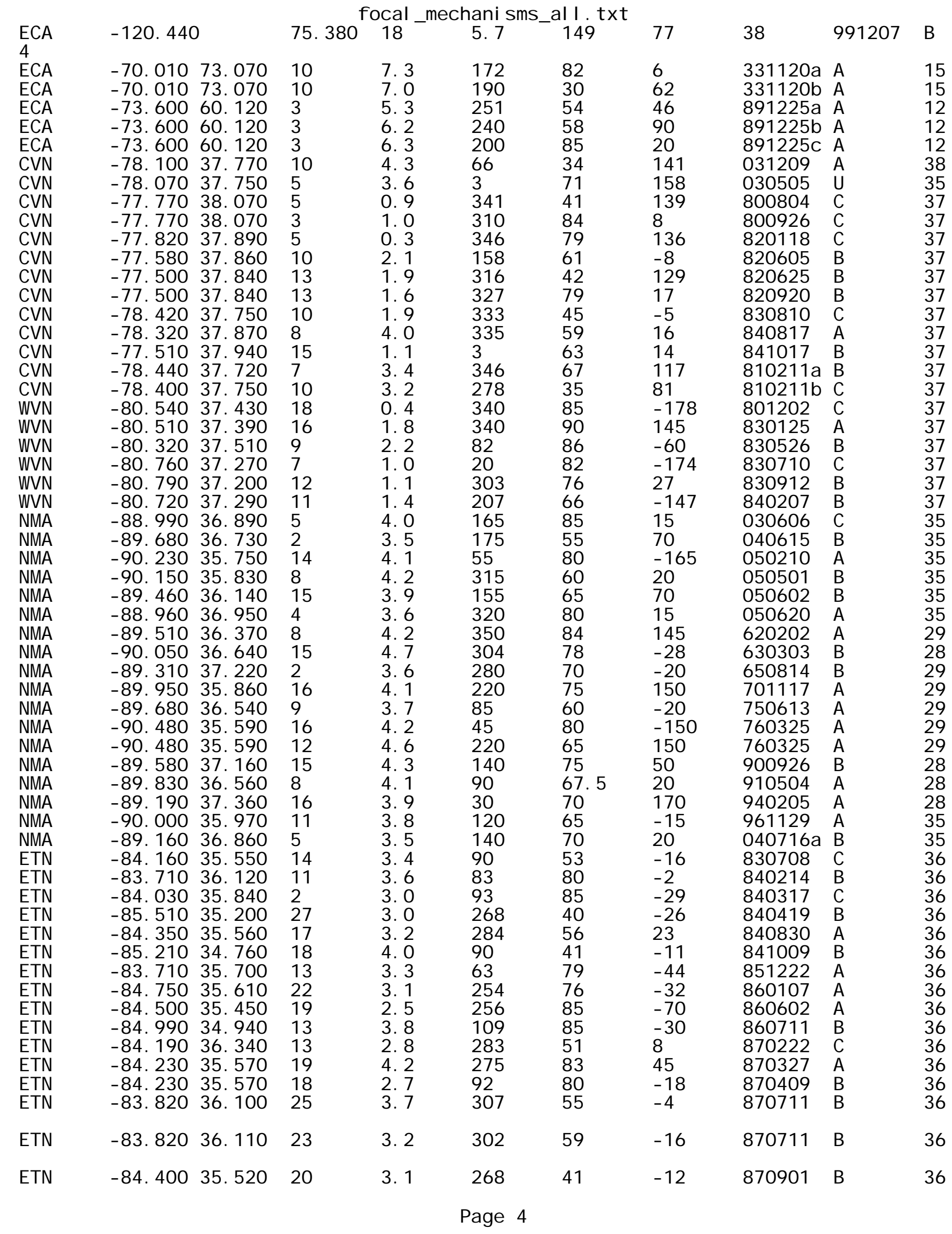




\begin{tabular}{|c|c|c|c|c|c|c|c|c|c|c|}
\hline ETN & -84.320 & 35.630 & 20 & cal & $\begin{array}{l}\text { hani s ms } \\
96\end{array}$ & $\left.\right|_{71} ^{11} \cdot \mathrm{txt}$ & -30 & 870922 & $B$ & 36 \\
\hline ETN & -84.190 & 35.280 & 13 & 2.9 & 300 & 62 & -22 & 880109 & $B$ & 36 \\
\hline ETN & -84.670 & 35.360 & 10 & 2.5 & 59 & 48 & -19 & 880213 & $C$ & 36 \\
\hline ETN & -83.820 & 35.330 & 1 & 3.5 & 332 & 50 & 23 & 880218 & $B$ & 36 \\
\hline ETN & -83.990 & 35.820 & 14 & 2.4 & 290 & 83 & -19 & 880311 & $C$ & 36 \\
\hline ETN & -84.210 & 35.780 & 18 & 2.3 & 261 & 55 & -30 & 880423 & $B$ & 36 \\
\hline ETN & -83.740 & 36.110 & 17 & 2.3 & 111 & 79 & -49 & 880424 & $A$ & 36 \\
\hline ETN & -84.430 & 35.500 & 23 & 2.9 & 266 & 73 & -58 & 890907 & $B$ & 36 \\
\hline ETN & -83.930 & 36.610 & 25 & 2.4 & 113 & 71 & -36 & 891202 & B & 36 \\
\hline ETN & -85.020 & 35.050 & 4 & 3.1 & 227 & 76 & -27 & 930115 & B & 36 \\
\hline $\mathrm{CHL}$ & -80.178 & 32.963 & 7 & 2.3 & 300 & 70 & 19 & 810319 & B & 39 \\
\hline $\mathrm{CHL}$ & -80.167 & 32.935 & 7 & 3.3 & 321 & 78 & 52 & 831106 & $B$ & 39 \\
\hline $\mathrm{CHL}$ & -80.146 & 32.941 & 5 & 1.9 & 357 & 49 & 121 & 871006 & $B$ & 39 \\
\hline $\mathrm{CHL}$ & -80.148 & 32.934 & 6 & 3.3 & 276 & 35 & 36 & 880123 & A & 39 \\
\hline $\mathrm{CHL}$ & -80.218 & 32.979 & 10 & 2.0 & 7 & 49 & 119 & 880623 & $C$ & 39 \\
\hline $\mathrm{CHL}$ & -80.158 & 32.929 & 7 & 2.0 & 325 & 40 & 90 & 890602 & A & 39 \\
\hline $\mathrm{CHL}$ & -80.155 & 32.930 & 7 & 1.6 & 350 & 90 & 175 & 890608 & A & 39 \\
\hline $\mathrm{CHL}$ & -80.152 & 32.949 & 5 & 2.8 & 13 & 52 & 161 & 900618 & B & 39 \\
\hline $\mathrm{CHL}$ & -80.140 & 32.932 & 6 & 2.7 & 347 & 77 & 113 & 900818 & C & 39 \\
\hline $\mathrm{CHL}$ & -80.130 & 32.945 & 4 & 3.4 & 10 & 56 & 110 & 901113 & C & 39 \\
\hline $\mathrm{CHL}$ & .80 .152 & 32.987 & 6 & 1.5 & 15 & 45 & 115 & 910824 & B & 39 \\
\hline EUS & .78 .900 & 46.870 & 10 & 4.6 & 116 & 68 & 69 & 000101 & U & 25 \\
\hline EUS & .74 .250 & 43.950 & 6 & 3.6 & 150 & 54 & 120 & 000420 & U & 25 \\
\hline EUS & -80.830 & 41.990 & 5 & 3.9 & 5 & 79 & 159 & 010126 & U & 25 \\
\hline EUS & -92.190 & 35.190 & 5 & 4.3 & 20 & 85 & -165 & 010504 & U & 35 \\
\hline \multirow{3}{*}{$\begin{array}{l}\text { EUS } \\
35 \\
\text { EUS } \\
35 \\
\text { EUS }\end{array}$} & -104.640 & & 37.150 & 3 & 4.2 & 215 & 30 & -80 & 010904 & U \\
\hline & -104.470 & & 37.140 & 2 & 4.4 & 190 & 25 & -130 & 010905 & U \\
\hline & -73.660 & 44.510 & 10 & 5.0 & 360 & 35 & 80 & 020420 & U & 35 \\
\hline EUS & -87.780 & 37.970 & 19 & 4.5 & 120 & 80 & 10 & 020618 & U & 35 \\
\hline $\begin{array}{l}\text { EUS } \\
\text { EUS } \\
\text { EUS } \\
\text { EUS } \\
\text { EUS }\end{array}$ & $\begin{array}{l}-98.900 \\
-80.070 \\
-85.500 \\
-85.500 \\
-101.750\end{array}$ & $\begin{array}{l}42.810 \\
32.360 \\
34.550 \\
34.550\end{array}$ & $\begin{array}{l}8 \\
9 \\
12 \\
12 \\
43.100\end{array}$ & $\begin{array}{l}4.1 \\
4.0 \\
4.6 \\
4.6 \\
15\end{array}$ & $\begin{array}{r}90 \\
350 \\
275 \\
275 \\
3.9 \\
\text { Page } 5\end{array}$ & $\begin{array}{l}50 \\
40 \\
75 \\
75 \\
85\end{array}$ & $\begin{array}{l}-110 \\
90 \\
5 \\
5 \\
60\end{array}$ & $\begin{array}{l}0211103 \\
0221111 \\
0330429 \\
030429 \\
-130\end{array}$ & $\begin{array}{l}U \\
U \\
U \\
U \\
030525\end{array}$ & $\begin{array}{l}35 \\
35 \\
35 \\
35 \\
U\end{array}$ \\
\hline
\end{tabular}


focal_mechanisms_al l. txt

35

EUS

EUS

EUS

35

EUS

35

35

EUS $\quad-88.960 \quad 41.440$

EUS

35

EUS $\quad-78.250 \quad 43.690$

EUS

EUS

EUS

EUS

EUS

EUS $\quad-82.800 \quad 35.880$

EUS

35

EUS

EUS

EUS

35

EUS

35

35

EUS

EUS

22

EUS $\quad-78.20042 .900$

EUS $\quad-90.440 \quad 37.440$

EUS

22

EUS

22

EUS

EUS

EUS

EUS

EUS

EUS

EUS

EUS

EUS

EUS

EUS

EUS

EUS

EUS

21

EUS $\quad-81.160 \quad 41.650$

EUS $\quad-84.390 \quad 40.550$

EUS $\quad-87.950 \quad 38.710$

EUS

$.87 .900 \quad 32.970$

$.69 .730 \quad 47.750$

.104 .900

$-104.700$

$.88 .370 \quad 37.910$

$.80 .580 \quad 33.310$

$-82.53033 .910$

$-89.40041 .600$

$.70 .900 \quad 45.300$

$-84.00035 .800$

.96 .00045 .700

.100 .700

$-66.65046 .980$

$-71.600 \quad 43.500$

.92 .21035 .170

.74 .26043 .940

\section{focal_mechanisms_all. txt}

$\begin{array}{llllllll}5 & 3.7 & 25 & 80 & -165 & 030816 & U & 35 \\ 36.850 & 4 & 4.1 & 170 & 55 & -100 & 030913 & U \\ 36.850 & 4 & 4.4 & 175 & 55 & -95 & 040322 & U \\ 32.530 & 3 & 3.9 & 345 & 50 & -120 & 040523 & U \\ 32.530 & 2 & 3.6 & 5 & 70 & -110 & 040622 & U \\ 7 & 4.2 & 20 & 90 & -165 & 040628 & U & 35\end{array}$

$\begin{array}{lllllll}36.890 & 4 & 4.3 & 155 & 65 & -120 & 040801\end{array}$

$\begin{array}{llll}3 & 3.2 & 125 & 65\end{array}$

$35 \quad 040804 \quad 0 \quad 35$

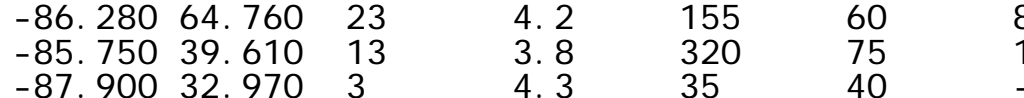

$12 \quad 4.6 \quad 350$

40

36.950

\section{9}

160

-115
80

8

$3.7 \quad 9$

90$$
40
$$

$4.1 \quad 230$

$-60$

$\begin{array}{lll}15 & 55 & 85 \\ 170 & 25 & 45\end{array}$

$-68.17044 .330$ 32.520

\section{$\begin{array}{ll}3.8 & 15 \\ 3.5 & 170\end{array}$}

$340 \quad 35$

$27.060 \quad 3.9$

4. 4

35
205

190
3.4

75

11
$36.930 \quad 5.6$

195

\section{0}

$\begin{array}{ll}40 & -70 \\ 70 & 20 \\ 165 & 52\end{array}$

39.900

4.6
4.3

110

165

52

$50 \quad 40$

$3 \quad 4.1 \quad 130$

$\begin{array}{ll}15 & 4.0 \\ 39.900 \quad 3 & \end{array}$

350

60

40
135
35

4. $5 \quad 158$

35

040804
040826

040912

041107

050306

$-110$

$U$

$U \quad 35$

$40.000 \quad 5$

52

22

$-86.500 \quad 64.400 \quad 12$

$\begin{array}{llll}-83.910 & 38.170 & 12\end{array}$

2

13

6

13

8

33.000

\section{$5.3 \quad 0$}

4. $6 \quad 162$

4. $4 \quad 260$

4. $0 \quad 350$

4. $1 \quad 170$

4. $5 \quad 300$

4. $1 \quad 190$

4. $3 \quad 310$

4. $3 \quad 330$

7
8

3

4.5

46

72

40

65

70
80

80
70

70
70
90

90
260

79

90

10

160

70

150

160

60

$60 \quad 18$

$\begin{array}{ll}5.0 & 30 \\ 5.1 & 200\end{array}$

4. 200

5. $0 \quad 330$

$\begin{array}{lll}9 & 4.9 & 170\end{array}$

42.370

$25 \quad 5.3$

60
35

60
70

70
350

125

120

55
115

115

80

$\begin{array}{ll}4.7 & 25 \\ 4.4 & 20\end{array}$

$-75.590 \quad 46.470 \quad 11$
0

$\begin{array}{ll}4.4 & 20 \\ \text { 5. } 0 & 135\end{array}$

4. 6

141

80
80
70
42

42

60

165
-170
15
90

$050825 \quad U \quad 35$

-85 o51219

060407 U 35

$060714 U \quad 35$

$\begin{array}{lll}061003 & U & 35 \\ .60 & 070103 & U\end{array}$

$\begin{array}{lll}070523 & U & 35 \\ .60 & 070609 & U\end{array}$

651021 A 29

$660101 \quad A \quad 29$

$\begin{array}{lll}.174 & 670410 \mathrm{U}\end{array}$

670613 A 29

$670721 \quad B \quad 28$

$.63 \quad 671127 \mathrm{U}$

$\begin{array}{lll}681109 & A & 29 \\ 711002 & A & 29 \\ 720203 & U & 24 \\ 720802 & U & 24 \\ 720915 & B & 29 \\ 730615 & A & 29 \\ 731130 & C & 29 \\ 740403 & B & 29 \\ 750709 & B & 29 \\ -60 & 780616 & \text { U }\end{array}$

$\begin{array}{lll}800727 & U & 23 \\ 820111 & U & 21 \\ 820119 & U & 21 \\ 820121 & U & 21 \\ 831007 & U & 21 \\ 335 & 841018 & U\end{array}$

$860131 \cup \quad 21$

$860712 \cup U 30$

$870610 \quad U \quad 31$

901019 U 25 


\begin{tabular}{|c|c|c|c|c|c|c|c|c|c|}
\hline $\begin{array}{l}\text { EUS } \\
\text { EUS }\end{array}$ & $\begin{array}{l}-73.46045 .200 \\
-103.300\end{array}$ & $\begin{array}{l}12 \\
30.260\end{array}$ & $\begin{array}{l}0 c \text { cal } \\
3.9 \\
20\end{array}$ & $\begin{array}{r}\text { hani } \\
144 \\
5.6\end{array}$ & $\begin{array}{c}\text { al } 1 \text {. } \\
45 \\
114\end{array}$ & $\begin{array}{l}96 \\
64\end{array}$ & $\begin{array}{l}931116 \\
-101\end{array}$ & $\begin{array}{l}U \\
950414\end{array}$ & $\begin{array}{l}25 \\
U\end{array}$ \\
\hline $\begin{array}{l}E \cup S \\
E \cup S \\
E \cup S \\
E \cup S \\
E \cup S \\
E \cup S \\
E \cup S \\
E \cup S \\
E \cup S \\
E \cup S \\
E \cup S \\
E \cup S \\
E \cup S \\
E \cup S \\
E \cup S \\
E \cup S \\
E \cup S \\
E \cup S\end{array}$ & 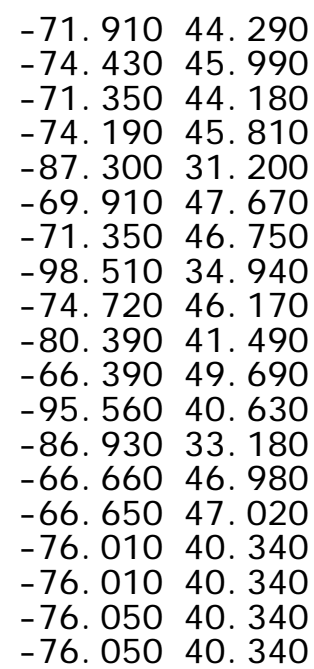 & $\begin{array}{l}6 \\
6 \\
7 \\
22 \\
5 \\
5 \\
12 \\
19 \\
9 \\
3 \\
5 \\
12 \\
4 \\
9 \\
6 \\
2 \\
3 \\
2 \\
3\end{array}$ & $\begin{array}{l}3.7 \\
3.7 \\
3.4 \\
3.6 \\
4.9 \\
4.3 \\
4.5 \\
3.9 \\
3.7 \\
4.5 \\
4.4 \\
3.5 \\
3.6 \\
5.5 \\
4.8 \\
4.0 \\
4.0 \\
4.6 \\
4.6\end{array}$ & $\begin{array}{l}95 \\
136 \\
144 \\
96 \\
94 \\
27 \\
39 \\
120 \\
150 \\
110 \\
30 \\
290 \\
30 \\
200 \\
215 \\
156 \\
121 \\
159 \\
135\end{array}$ & $\begin{array}{l}50 \\
36 \\
60 \\
33 \\
62 \\
66 \\
63 \\
70 \\
27 \\
70 \\
63 \\
55 \\
30 \\
45 \\
60 \\
45 \\
60 \\
48 \\
49\end{array}$ & $\begin{array}{l}40 \\
98 \\
93 \\
60 \\
-90 \\
111 \\
87 \\
-60 \\
75 \\
20 \\
93 \\
-135 \\
-100 \\
120 \\
130 \\
108 \\
66 \\
102 \\
68\end{array}$ & $\begin{array}{l}950616 \\
960314 \\
960821 \\
970524 \\
971024 \\
971028 \\
971106 \\
980428 \\
980730 \\
980925 \\
990316 \\
040716 b \\
040819 b \\
820109 a \\
820109 b \\
940116 a \\
940116 a \\
940116 b \\
940116 b\end{array}$ & $\begin{array}{l}U \\
U \\
U \\
U \\
U \\
U \\
U \\
U \\
U \\
U \\
U \\
U \\
U \\
U \\
U \\
U \\
U \\
U \\
U\end{array}$ & $\begin{array}{l}25 \\
25 \\
25 \\
25 \\
35 \\
25 \\
25 \\
35 \\
25 \\
34 \\
25 \\
35 \\
35 \\
21 \\
21 \\
25 \\
33 \\
25 \\
33\end{array}$ \\
\hline
\end{tabular}




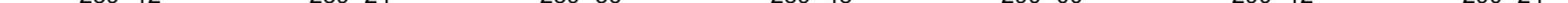


Charlevoix stress field

\author{
charlevoix-classification.txt
}

median $90 \% \mathrm{Cl}$

Groups with SHmax sub-parallel to local "tectonic" SHmax, about N050 $042-050$

1 - subset below North shore (NW of mid-river splitting line) N046 $039-065$

2 - subset inside small crater (part of 1 , except 2 eq) N052

$2 b$ - subset central NW (central part of 1 )

N0 54

$036-073$

Same but with larger spread or poorer agreement

3 - subset west of E289.85 (s half of $1+7$ eq)

$048-074$

N058

4 - subset ND2 (s part of $1+2$ eq)

N0 61

5 - subset ND4 (small cluster below NW shore) N065

$045-085$

$5 b$ - subset $S W$ ( $S W$-most part of 1 , poorly resolved)

N059

Groups with SHmax most oblique to local tectonic stress

6 - subset below east side of river (SE of mid-river line) N103

$091-115$

7 - subset outside large crater (si milar to 9)

N 105

$091-119$

8 - subset depth> $12 \mathrm{~km}$ (mostly $S E+f e w N W$ eq)

N 116

$094-139$

9 - subset ND1 ( $N$ end of CHV, similar to 7)

$095-120$

N 108

Same but with larger spread or poorer resolution

10 . subset ND3 (but apparently bi modal, poorly resolved?)

N123

$105-140$

11. subset TD5 (depth $20-23 \mathrm{~km}$, mix spatial distribution)

N115

$085-145$

12 . subset central SE (central part of 2 )

N111

Conclusions

(1) Events below North shore (NW of mid-river I ine) show SHmax N050, parallel to local tectonic SHmax

possible exceptions:

3 events at NW end that may be part of $N$-end group (case 9 above)

2 SE events included in ND2 may be part of this group

(2) Groups showing maxi mum SHmax rotation are North End cluster (ND1, case 9 above), outside arge crater

I arge

(same as NDI-North End), central SE cluster, and below east side of river at 